\title{
SUSTAINABLE DEVELOPMENT GOALS, RULE OF LAW AND PUBLIC POLICY: IMPLICATIONS FOR THE TRADITIONAL FAMILY MODEL
}

\author{
OBJETIVOS DE DESARROLLO SOSTENIBLE, ESTADO \\ DE DERECHO Y ORDEN PÚBLICO: IMPLICACIONES PARA \\ EL MODELO DE FAMILIA TRADICIONAL
}

\author{
Armando Alvares Garcia JúNIOR \\ Former Dean of the Faculdade de Direito da Universidade Bandeirante de Sāo Paulo (Brazil) \\ Chairman of the American Society of International Law: Private International Law / Teaching \\ International Law Interest Groups (U.S.A.) \\ PhD in Law and PhD in Political Science (International Relations) \\ Professor of Universidad Internacional de La Rioja (Spain) \\ Arbitrator \\ Honorary Collaborator of ACCURSIO DIP \\ Orcid: 0000-0002-5950-978X
}

Recibido: 15.06.2021 / Aceptado: 12.07.2021

DOI: https://doi.org/10.20318/cdt.2021.6308

\begin{abstract}
Based on international public policy as an extension of national sovereignty, governments with authoritarian deviations are reforming their constitutions, criminal laws, etc. with the aim of preserving the inalienable values of their States and the Christian roots of their societies (traditional marriage and family model). For this purpose, basing on the vertical conception of SDG 16 (in which the areas of peace and justice are subordinated to the area of strong institutions), they seek to strengthen the state by gradually annulling its "disintegrating factors": Muslim immigrants and refugees, members of the LGBTI community, leftist politicians, independent journalists and the EU itself (values, legislation and its incipient public policy). The research analyzes this problem affecting the family and its rights.

Keywords: Public Order, Rule of Law, Sustainable Development Goal 16, traditional Christian family model.

Resumen: Con base en el orden público internacional como expresión de la soberanía nacional, gobiernos con desviaciones autoritarias están realizando reformas constitucionales, penales, etc. con el propósito de preservar los valores inalienables de sus Estados y las raíces cristianas de sus sociedades (modelo de matrimonio y familia tradicional). Para eso, con base en la concepción vertical del ODS 16 (en que los ámbitos paz y justicia se supeditan al ámbito instituciones sólidas), buscan fortalecer el Estado mediante la gradual anulación de sus "factores de desintegración": inmigrantes y refugiados musulmanes, miembros de la comunidad LGBTI, políticos de izquierda, periodistas independientes y la propia UE (valores, legislación y su incipiente orden público). La investigación analiza este problema que afecta a la familia y sus derechos.
\end{abstract}

Palabras clave: Orden público, Estado de Derecho, Objetivo de Desarrollo Sostenible 16, modelo de familia tradicional cristiano. 
Summary: I. Introduction. II. Public Policy and the rule of law: basic comments. III. Rule of Law and Sustainable Development Goals. IV. SDG 16: horizontality and verticality of peace, justice and strong institutions. V. SDG 16: international public order, nationalist politics and the defense of marriage and the traditional Christian family. VI. Conclusions.

\section{Introduction}

1. In a consolidated integration process such as that of the European Union (EU), the formation of a genuine European public order, based on its fundamental values, formally considered common and shared by its Member States (respect for human dignity, freedom, democracy, equality, the rule of law and respect for human rights, including the rights of persons belonging to minorities, according to Art. 2 of the Treaty on European Union, TEU) should be feasible. The second part of this article even makes it explicit that "these values are common to the Member States in a society characterized by pluralism, non-discrimination, tolerance, justice, solidarity and equality between women and men"1.

2. At the EU level, the rule of law is the necessary prerequisite for the protection of all these fundamental values, as well as for protecting the rights and duties enshrined in international law and in the EU's own treaties or in the EU's treaties with third countries or groups of countries ${ }^{2}$. However, the rule of law can promote both the European public order and the international public order of its member states, depending on the emphasis placed on it.

3. As will be discussed in due course, the Sustainable Development Goals (SDGs), specifically SDG 16, by highlighting the national dimension of the rule of law, strongly favour the international public order, in turn extolled by conservative and extreme right-wing political parties ${ }^{3}$, which advocate the "defense of the traditional Christian family"4 as part of their "genuinely national" values. In this sense, it is not surprising that they exalt the international public order" as an expression of their national sovereignty that plays a defensive role in the moral, social and legal order of the country, capable of antagonizing the European public order, still in progress but supranational and, for this reason, potentially "invasive" or "disaggregating".

\section{Public Policy and the rule of law: basic comments}

4. Some conservative political parties -especially in Eastern Europe- backed by international public order, are seeking to prioritize what they consider to be the fundamental and inalienable values and principles of their states, consonant with the collective interests and very existence of their societies $^{6}$. International public order is presented as a defensive shield of the moral, social and legal order of

This idea extends to the basic principles which guide the EU's action on the international stage and which inspired its creation, development and enlargement and which it seeks to promote in the rest of the world (Art. 21 TEU): democracy, the rule of law, the universality and indivisibility of human rights and fundamental freedoms, respect for human dignity and equality -consistent with fundamental values- plus solidarity and respect for the principles of the United Nations Charter and international law.

2 K. L. Cheppele, D. V. Kochenov, B. Grabowska-Moroz, "EU values are law, after all: Enforcing EU values through systemic infringement actions by the European Commission and the member states of the European Union", Yearbook of European Law, no 39, 2021, pp. 3-121.

${ }^{3}$ B. Sirm, C. FiIG, "The populist challenge to gender equality”, en G. Abels, A. Krizsán, H. Macrae, A. Van Der Vleuten (coords.), The Routledge Handbook of Gender and EU Politics, Routledge, Abingdon, 2021, pp. 367-378.

${ }^{4}$ C. JoppKe, "Populism and the double liberalism: exploring the links", Theory and Society, Vol. 50, March 2021, pp. 1-22.

${ }^{5}$ In turn, domestic public policy would comprise all coercive provisions that cannot be set aside by the will of the parties, including equal marriage.

${ }^{6}$ R. CSEHI, E. Zgut, “'We won't let Brussels dictate us': Eurosceptic populism in Hungary and Poland”, European Politics and Society, Vol. 22, n ${ }^{\circ} 1,2021$, pp. 53-68. 
the forum ${ }^{7}$ against "external interference" and the undesirable attempts to make it more flexible by the European public order which, contradictorily, does not even recognize its existence, but does recognize its risks.

5. However, it is one thing to exclude, on the basis of the State's international public policy, the application of foreign law, and quite another to try to prevent EU law from being applied in its Member States. The international public policy may exclude the normal application of the competent foreign law due to its manifest incompatibility with those (value-laden) principles considered fundamental in the legal system of the forum and whose negative impact (externality) would be generated on a particular society (supra-individual structure), even if the regulation by the competent foreign law is fair for the parties involved in the specific case ${ }^{8}$.

6. Traditionally, if the applicable foreign law is contrary to the public policy of the country where it is intended to apply, it must be replaced by the law of the forum (Lex Fori ${ }^{9}$ ). But can this rationing reach EU law relatively to its Member States? Of course, EU law should not be confused with the law of a foreign country. On the contrary, EU law must apply equally in all EU Member States. It is up to the Court of Justice of the European Union (CJEU) to ensure this.

7. The EU's fundamental principles and values are supposed to be common and shared by its Member States. However, there is a growing lack of respect for these elements and even for EU law ${ }^{10}$. Under the argument of defending the Christian roots of society and the traditional Roman Catholic marriage and family model (the current governments of Hungary and Poland could be mentioned as paradigmatic examples in this regard) the divergence has been straining the ropes since the rise to power of the far-right Fidesz and Law and Justice parties, respectively. Recent institutional reactions at the EU level, while condemning such "national and nationalist" positions, have not succeeded in softening the virulence of the political attacks (and the legal measures taken by these countries against certain groups). In fact, their attacks are directed at European values, EU law and, of course, at those collectives (or individuals in particular) considered undesirable according to the position of the governing parties.

8. Technically, public order is invoked to counter negative disturbances in the forum, but it is neither clear nor proven that EU values and norms actually undermine the basic and inalienable principles and values of these countries'legal systems, no matter how much their political leaders may vociferate $^{11}$. At the domestic level, the "debate" on the core values and principles of these societies has become politicized and legal opinions have become risky. This generates significant noise, confusion and bias. It is not surprising, therefore, that there is greater political control over the prosecution, the judiciary and the media in these countries ${ }^{12}$.

\footnotetext{
${ }^{7}$ In the field of private international law, this public order can be found, among other instruments, in the Inter-American Convention on General Rules of Private International Law (arts. 5-8), Bustamante Code (arts. 4 and 5), and in many other conventions. It is important to note that constitutional precepts are considered to be international public order, i.e., they contain a set of principles of public or private law considered fundamental for the organization and functioning of the State. For this reason, it is not surprising that those countries that generate restrictions related to the family model choose -although not only for this reason- to reform their constitutional rules (constitutional reform would supposedly allow the state to oppose the application of EU law) and to produce mandatory rules of infra-constitutional rank in this field which would affect, above all, national public order.

8 J. Carrascosa GonzÁlez, "Orden público internacional y externalidades negativas", Boletín del Ministerio de Justicia, Vol. 62, n 2065, 2008, pp. 2351-2378.

${ }^{9}$ If the rules of conflict present a single point of connection (Latin system), with the exception of public policy and its positive or substitutive effect, the substantive law of the forum would apply. In turn, in cases of multiple connections, if the main connection designates a foreign law whose application is not feasible because it is contrary to the international public policy of the country, the other points of connection would be applied successively and, finally, the substantive law of the forum (subsidiary system).

10 Vid Note 2.

${ }^{11}$ A. O. YAssen, "The Failure of the European Union to Respond to the Refugee Crisis", Turkish Journal of Computer and Mathematics Education (TURCOMAT), Vol. 12, nº 2, 2021, pp. 302-311.

12 J. Petrov, "(De-) judicialization of politics in the era of populism: lessons from Central and Eastern Europe", The International Journal of Human Rights, May 2021, pp. 1-26.
} 
9. As far as the competent foreign law is concerned, by its very nature, the public policy exception must be considered restrictively and only in order to prevent its application from generating pernicious inconsistencies in the central axes of the legal order of the forum, which would cause serious damage to society as a whole ${ }^{13}$. Several problems can be observed in totalitarian states. Just to mention two of them: (1) members of the judiciary are fearful of political persecution and assess the assumptions of the specific international case in a more biased way and (2) the international public order of these countries is often very aggressive in comparison to that of democratic states (it is not objective to discuss illiberal democracies here) and tends to significantly reduce the freedom of the parties -through the regulation by mandatory rules- of their private-legal relations, especially in matrimonial and parentage law ${ }^{14}$. Foreign law is therefore much less applied in these countries because of the higher incidence of collisions with their public order. Although the idea of safeguarding the principle of justice often appears in the background of public order, justice in these countries is interpreted in a biased way, which contradictorily generates various injustices for those who represent a real or imagined danger to the Christian roots and the traditional marriage and family model that the political parties claim to defend. This often includes homosexuals, Muslim immigrants or Muslim asylum seekers, left-wing sympathizers or politicians (including any political opponents), human rights defenders, independent journalists or those critical of the system, etc.

10. International public order is composed of principles (political, religious, economic, legal -both public and private- and moral) that are considered basic (or fundamental), absolutely necessary for the preservation of social order and the protection of the cohesion, stability and proper functioning of the

13 Doctrine, jurisprudence and legislation often consider the existence of a "partial" international public policy, which would lead to the non-application of foreign provisions whose application is contrary to the international public policy of the (forum) State, although other foreign provisions that are not contrary to the fundamental principles of the law of that State would apply (e.g., Judgment of the Court of Cassation, France, 8 November 1943, Fayeulle, RCDIP, 1946, p. 273). The Rome Convention of 19 June 1980 on the law applicable to contractual obligations expressly provided for partial public policy in its Art. 16, as does Regulation (EC) 864/2007 of the European Parliament and of the Council of 11 July 2007 on the law applicable to non-contractual obligations (Rome II Regulation) in its Art. 26. However, with the political pressure exerted on the competent authorities in countries such as Hungary and Poland, the provisions considered applicable are in danger of being increasingly reduced in scope, due to the tendency - still incipient but growing - to consider the whole set of provisions and their consequences as offensive to public policy. The same fate seems to occur in relation to the theory of "attenuated" international public policy. It usually distinguishes between: (1) legal situations intended to be created in a country under a foreign law, the application of which would violate the basic principles of its law and injure the cohesion of its society and (2) legal situations already legally created in a foreign country under the competent law (its own, normally). In the first case, the public policy of the forum would apply in its entirety (e.g., the impossibility of celebrating an egalitarian marriage or a polygamous marriage in those States that do not admit them). The foreign law would not apply and, consequently, a new legal situation would not be created in the country. This would occur because the damage to the basic legal structure or the cohesion of the society of the forum country is "intense". In the second case, the legal situation already created abroad would have a much "weaker" impact, so that the application of the State's international public policy would be restricted only to the so-called "nuclear" legal effects because its admission would produce substantial damage both to the basic legal structure and to the social cohesion of the country whose courts hear the case (e.g., civil registration of polygamous marriages in countries that do not accept it). On the other hand, the so-called "peripheral" effects would not be contrary to the international public policy of the country. With this criterion, the aim would be to preserve the legal security of situations legally constituted abroad, avoiding their invalidation by the mere crossing of borders. Thus, without applying the foreign law, some of its legal effects would be recognized (e.g., request for alimony or a post-divorce pension from a second wife in a marriage registered in the country). For states with authoritarian deviations, this theory could succumb to the same problem mentioned above. Finally, the international public policy of proximity, which considers both the proximity and the minimum necessary linkage of the factual assumptions in relation to the country whose courts hear the case (since these would be precisely those that may affect the national society). In the absence of regulatory provision, it is usually the courts that would specify this link for the specific factual situation, generally considering: (1) nationality; (2) nationality and habitual residence (cumulatively or alternatively). In some countries (e.g., Germany, Switzerland) this theory is assumed with its own nuances. In others (e.g., Spain or France) its acceptance is considerable. In States with very broad forums of international jurisdiction, the public policy of proximity is not often activated, although this is possible in those cases where there is voluntary submission to the forum by the parties. There is no uniform position adopted by authoritarian States regarding the greater or lesser extent of this forum. Some countries seek to broadly cover different legal situations involving their nationals (the trend seems to be to include residence as an alternative assumption). Other States, however, choose to maintain a more limited profile as far as private international legal relations are concerned. Vid Note 8.

14 Vid Note 8. 
basic legal architecture of a specific society in a specific epoch or historical period and which cannot be undermined ${ }^{15}$. As such, they reflect the general interests of society and embody its most precious, essential and inalienable values at a particular point in time. For this reason, the idea of timelessness invoked by the ruling political parties in Hungary and Poland is not congruent with the understanding on the legal level. Without going into the subject, it can be stated that culture is not static, but a dynamic amalgam of factors ${ }^{16}$. The same is true of social relations, except in very particular cases of isolation for political reasons. As is well known, the international public order invoked by states is, in fact, state-based. Each state organizes the coexistence of its society according to its own rules (the state has its own set of basic principles) and presents its own international public order ${ }^{17}$.

11. As the content of international public policy is diffuse, it is up to the judicial authorities (not the political authorities) to analyze whether the solution reached by the foreign rule is manifestly contrary to the essential principles enshrined in the legal system of the forum, something which, moreover, may change over time. If it affects the structural elements of the legal system of the forum -those that are responsible for the organization of the society-, then the application of the foreign rule should be excluded $^{18}$. The application of public policy is exceptional (i.e., the application of the competent foreign law is the rule) and, for that reason, it must be interpreted and applied restrictively. In fact, it should only operate if, in the specific case, the foreign law designated as applicable by the national conflict rule violates the basic legal structure of the country whose courts hear the case and disturbs the legal cohesion, the proper functioning and the stability of the respective society. When invoking the public policy exception, the judicial authority must assess the different circumstances of each case based on two crucial stages: the analysis and calibration of the principles contained in the national legal system according to the degree of sensitivity and social consensus that exists on them, and the weighing of whether the principles involved in the case are effectively violated by the application of foreign law. This delicate activity of the judiciary is under pressure from political powers in several countries. As a consequence, negative effects are being generated on marriages and unions between persons of the same sex or involving non-Christian foreigners.

12. The flexibility of the public policy exception is usually due to rights validly acquired abroad according to the competent rule of the country. This issue has given rise, for example, to discussions in different countries about the generation of certain effects in polygamous marriages validly entered into in foreign countries. The more the interpretation of the norm is subordinated to politics (especially if there is a totalitarian matrix), the greater the bias and the greater the risk of collision with public order. Countries such as Hungary or Poland (e.g.) strive to exalt the fundamental principles of their legal systems through constitutional reforms led by ultra-conservative parties, so that the scope for the extension of the application of public order tends to be considerably greater as well.

13. Some political leaders in the above-mentioned countries claim that the immutable, timeless, unrenounceable, etc. principles and values of the state and society are at enormous risk of deterioration due to domestic and foreign disaggregating factors. The domestic factors would include, for example, communists, homosexuals, progressive journalists, etc. and the foreign factors would include Muslim immigrants, non-Caucasian asylum seekers, "liberal" organizations that promote pluralism, etc. and, in the regulatory framework, even foreign law, EU law and EU values! ${ }^{19}$. The idea of blame ("due to or because of") is symptomatic. As will be seen elsewhere in this research, it is part of the current politi-

\footnotetext{
15 Vid Note 8.

${ }^{16}$ Culture is not static, but a dynamic amalgam of factors. The same applies to social relations, except in very particular cases of isolation in dictatorial regimes (Y. Gorodnichenko, G. Roland, "Culture, institutions and democratization", Public choice, Vol. 187, n 1, 2021, pp. 165-195).

17 Vid Note 8.

18 Vid Note 8.

19 Z. Kinowska-Mazaraki, "The Polish Paradox: From a Fight for Democracy to the Political Radicalization and Social Exclusion”, Social Sciences, Vol. 10, nº 3, 2021, pp. 1-16.
} 
cal narrative of social polarization. Expressions such as "we seek the union of all against the common enemies", the "enemies of our freedom", of "our way of life", of "our values and principles", of "our Christian roots", of "our model of family and marriage", etc. are part of the discourse of current rightwing populism seen today in many countries around the world ${ }^{20}$. Essentially, the access of the foreign element, be it individuals, organizations or norms (including EU law and values!) must be "controlled" for the benefit of the state and its society. After all, national society cannot be "contaminated" by national or, mainly, foreign principles, values, norms and individuals. This is the tone of right-wing populist nationalism, despite the fact that the world is hyper-connected and that Central and Eastern European member states account for a large part of EU funds.

14. Constitutional precepts are considered to be international public policy, i.e., they contain a set of principles of public or private law considered fundamental for the organization and functioning of the state and society ${ }^{21}$. It is therefore not surprising that the aforementioned countries are carrying out constitutional reforms (which would supposedly allow the state to oppose the application of EU law by reinforcing its international public order) while at the same time massively producing mandatory rules of infra-constitutional rank ${ }^{22}$.

15. The attempt to "legitimize" the exercise of an extraordinarily aggressive police power ${ }^{23}$ by the state would seek, as an ultimate aim (according to certain political parties), the preservation and promotion of the general interest (morality, health, peace, public and social security, etc.). In such a context, the "traditional Christian family" (consisting of a woman and a man) 2 $^{24}$ as the fundamental nucleus of society, would be at risk due to its exposure to various disintegrating factors (immigration, left-wing ideologies, the LGBT community and ideology ${ }^{25}$, Islamism and even the existence of a European public $\operatorname{order}^{26}$ whose values no longer seem to be fully shared ${ }^{27}$ ). The profuse editing of mandatory laws in some of these countries ${ }^{28}$-such as, for example, Poland and Hungary- may, however, move away from the rule of law. Indeed, recent constitutional, penal and penitentiary reforms in the above-mentioned countries and in several others (including Denmark and its new refugee law) lead to the consolidation of this problem.

16. Under the argument of protecting the Christian roots and values of society ${ }^{29}$, and therefore its traditional family model, the diffuse notion of public order seems to facilitate the action of certain governments $^{30}$. Technically, public order is constructed on the basis of principles that embody fundamental and

${ }^{20}$ C. M. Michael, Migration and the Crisis of Democracy in Contemporary Europe, Palgrave Macmillan, Cham, 2021, pp. 159-235.

${ }^{21}$ N. Neuwahl, C. Kovacs, "Hungary and the EU's Rule of Law Protection”, Journal of European Integration, Vol. 43, n 1, 2021, pp. 17-32.

22 Vid Note 14

${ }^{23}$ M. Neocleous, A Critical Theory of Police Power: The Fabrication of the Social Order, Verso, London, 2021, p. 73.

24 R. Mole, A. Golec De Zavala, M. Murat Ardag, "Homophobia and national collective narcissism in populist Poland", European Journal of Sociology, 2021, retrieved from https://discovery.ucl.ac.uk/id/eprint/10122902/1/Homophobia\%20 and $\% 20$ collective $\% 20$ narcissism $\% 20$ in $\% 20$ populist $\% 20$ Poland $\% 20 \% 28$ final $\% 29$.pdf.

${ }^{25}$ In Poland, several towns proudly display "LGBT-free zone" banners, following a line taken by the government controlled by the ultra-conservative Law and Justice party. Both Hungary and Poland consider the current defense of LGBT rights as a foreign idiom, as it has emerged in the United States in 1969 with the Stonewall riots and subsequently copied by Western Europe, which would threaten the traditional heterosexual family in those countries (which they seek to protect as the fundamental core of society).

${ }^{26}$ S. LAVENEX, W. WAGNER, "Which European public order? Sources of imbalance in the European area of freedom, security and justice", European security, Vol. 16, no 3-4, 2007, pp. 225-243.

${ }_{27}$ A. SAntana, P. ZAGÓRSKI, J. RAma, "At odds with Europe: explaining populist radical right voting in Central and Eastern Europe", East European Politics, Vol. 36, n 2, 2020, pp. 288-309.

${ }^{28}$ P. Swianiewicz, "From post-communist democratic laissez-faire to prevention of territorial fragmentation: tightening the rules of municipal splits in Central and Eastern Europe after 1990", Miscellanea Geographica. Regional Studies on Development, Vol. 25, $\mathrm{n}^{\circ} 1,2021$, pp. 5-17.

${ }^{29}$ C. RuzzA, "The institutionalisation of populist political discourse and conservative uncivil society in the European Union: From the margins to the mainstream?", Nordicom Review no 42, 2021, pp. 119-133.

30 B. Jordan, Social value in public policy, Springer Nature, London, 2021, pp. 36-47. 
inalienable values of the state and that are embodied in constitutional and infra-constitutional legal norms. By assuming the idea that they represent the most vital collective interests, and therefore the most valuable for the existence of a particular society at a particular historical moment ${ }^{31}$, a longer arm would be conferred on the action of certain states, which naturally tarnishes the existence of a European public order.

17. The EU's clash ${ }^{32}$ with Hungary, Poland or, in the near future, Denmark, reveals a war of ideological values that has its direct basis in public order. If it is essentially national and representative of a particular society, its governments -usually illiberal democracies ${ }^{33}$ - may produce or reform norms with the purpose of making it difficult for indigenous people to intermarry with non-Caucasian individuals, or to scorn non-traditional marriage patterns in a Christian perspective.

18. Taking into account that public order, generically considered, would legitimize the exercise of the state's police activity (the purpose of which is to preserve and promote social tranquility, peace and security, sanitation, health, imperative laws, public morality (predominant in a democratic Society), good customs, general interest, etc.), any "external factor" (Muslim immigrants and refugees, gays ${ }^{34}$ and even the supposedly "alien" European public order are considered potentially debilitating or fragmenting the society whose state, represented by the government, claims to protect.

19. Internal public order comprises all coercive provisions that cannot be set aside at the will of the parties. For contemporary constitutional states, internal public order, in its public sphere, thanks to the principle of legality, would seek to prevent administrative discretionality from being transformed into arbitrariness ${ }^{35}$. The problem is more difficult to solve when the rules themselves are discriminatory, because they tend to be backed by public policy. In this case, the rule of law will have to be invoked, which would assume an absolutely primordial role. Countries such as Hungary, Poland or Czech Republic have not managed to prevent administrative discretionary power from turning into arbitrariness and discrimination in the service of political parties ${ }^{36}$, albeit camouflaged as legality (e.g., prohibition of egalitarian or establishment marriage).

20. In its private sphere, on the one hand, national public order would legitimize the exercise of fundamental rights and public freedoms recognized in the Constitution and, on the other, it would seek to limit the autonomy of the will and the exercise of acts contrary to the collective interests of the community.

21. With the authoritarian drift observed in Hungary and Poland, for instance (but which extends to a greater or lesser degree to other countries, European ${ }^{37}$ and non-European ${ }^{38}$ ), is that the national public order, in its private sphere, is quite questionable. In fact, it is serving as a basis for the restriction of

\footnotetext{
${ }_{31}$ M. Brake, C. Hale, Public Order and Private Lives (Routledge Revivals): The Politics of Law and Order, Routledge, Abingdon, 2013, p. 157.

${ }^{2}$ M. AvbeLJ, "Security and the Transformation of the EU Public Order", German Law Journal, Vol. 14, no 10, 2013, pp. 2057-2073.

33 A. Biró-NAGY, "Illiberal democracy in Hungary: The social background and practical steps of building an illiberal state", en P. Morillas (coord.), Illiberal Democracies in the EU: the Visegrad Group and the Risk of Disintegration, CIDOB, Barcelona, 2017, pp. 31-44.

${ }^{34}$ P. Lutz, F. Karstens, "External borders and internal freedoms: how the refugee crisis shaped the bordering preferences of European citizens", Journal of European Public Policy, Vol. 28, n 3, 2021, pp. 370-388.

${ }_{35}$ Z. VuKašInović-RadojIčić, V. Čogurić, "Convergence and symbiosis of public administration principles: International and European perspective", Bezbednost, Beograd, Vol. 63, n 1, 2021, pp. 5-18.

${ }^{36}$ M. F. Durmaz, "The transition from Europeanisation to de-Europeanisation in Hungary and the Czech Republic: case of rule of law", Master's thesis, Türk-Alman Üniversitesi, Sosyal Bilimler Enstitüsü, 2021, retrieved from http://openaccess.tau.edu.tr/xmlui/bitstream/handle/20.500.12846/504/27F139C885EBDC9CFB7A1AF195A5F1C1BED7DED5AF9A23F84423EA36061CACDC.pdf?sequence $=1$ \&isAllowed $=\mathrm{y}$

${ }^{37}$ K. Raube, F. Costa Reis, "The EU's crisis response regarding the democratic and rule of law crisis", en M. RidDERvold, J. Trondal, A. Newsome (coords.), The Palgrave Handbook of EU Crises, Palgrave Macmillan, Cham, 2021, pp. 627-646.

38 C. M. Renshaw, "Southeast Asia's human rights institutions and the inconsistent power of human rights", Journal of Human Rights, Vol. 20, nº 2, 2021, pp. 176-193.
} 
the exercise of rights and freedoms ${ }^{39}$ enshrined in European law with which these countries must comply (their governing parties take advantage of their absolute majority to modify rules of constitutional rank that underpin public freedoms). Moreover, there is an accentuated tendency to limit the autonomy of will when it runs counter to what these same parties call the "collective interests" of their societies.

22. The growing conflict between the internal and, especially, the international public order of some EU member states and the European public order, not yet established, despite the positive contribution of the European courts ${ }^{40}$ in matters affecting family law and other related matters, only emphasize the importance attributed by certain countries to their own set of (national) values to the detriment of another allegedly shared with the other members referred to at the beginning of the text. In any case, the actions of both public leaders and ordinary citizens should be underpinned by the rule of law, the cornerstone of the EU itself, but whose paradigm shift promoted by the 2015 SDGs has shifted the balance towards the state and international public order.

\section{Rule of Law and Sustainable Development Goals}

23. When the European Commission adopted a new rule of law framework in 2014 to complement the infringement procedures provided for in Article 7 TEU (which even allows, as a last resort, in cases of serious and persistent violation of the EU's fundamental values by one of its members, the suspension of their voting rights in the Council), the possibility of initiating a constructive dialogue ${ }^{41}$ between that institution and the offending state in order to prevent the continuation of its conduct was established. This was a prior, logical and necessary step towards establishing a European public order, respectful of the values, rights and freedoms enshrined and, naturally, congruent with the rule of law ${ }^{42}$.

24. Unfortunately, both the "preventive mechanism" of Article 7(1) (activated in cases where there is a "clear risk of a serious breach", which allows the Council to warn a country before such a breach occurs) and the "sanction mechanism" of Article 7(2) (activated in cases of "serious and persistent breach by a Member State" of the values stipulated in Article 2, and which allows the Council to suspend certain rights deriving from the application of the treaties in the country) have failed ${ }^{43}$ to prevent several situations of crisis in the rule of law, with the result that the formation of European public order has been hindered on several occasions. In fact, by requiring unanimity in the European Council, their approval is extremely difficult to achieve in practice.

25. Since 2009, the Commission, with the complementary role of the other EU institutions, has sought to address these situations by exerting political pressure and establishing infringement procedures in the event of violations of European law, notably through requests for the European Parliament to assess the continued respect for fundamental values, democracy and the rule of law, and, since 2014, through the annual dialogue between the Council and all EU countries to promote and protect the rule of law within the normative framework of the treaties. As early as 2015 , with the commitments made by the EU and its member states within the framework of the SDGs, the expectation was that the rule of

${ }^{39}$ G. S. Belyaeva, V. V. Gelunenko, E. E. Tonkov, L. I. Nikonova, D. V. Gavrishov, "Constitutional Freedom of Speech in

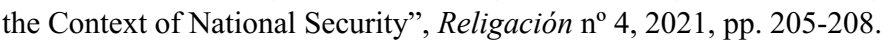

40 L. Conant, "The Court of Justice of the European Union", en M. Riddervold, J. Trondal, A. Newsome (coords.), The Palgrave Handbook of EU Crises, Palgrave Macmillan, Cham, 2021, pp. 277-295.

${ }^{41}$ M. BonelLi, "From Sanctions to Prevention, and Now Back to Sanctions? Article 7 TEU and the Protection of the EU Founding Values", en S. Montaldo, F. Costamagna, A. Miglio (coords.), EU Law Enforcement. The Evolution of Sanctioning Powers, Routledge, Abingdon, 2021, pp. 47-69.

${ }^{42}$ A. NowAK-FAR, "The Rule of Law Framework in the European Union: Its Rationale, Origins, Role and International Ramifications”, en A. Von Bogdandy, P. Bogdanowicz, I. Canor, C. Grabenwater, M. Taborowski, M. Schmidt (coords.), Defending Checks and Balances in EU Member States, Springer, Berlin/ Heidelberg, 2021, pp. 305-331.

43 Vid Note 32. 
law would be strengthened and, therefore, the European public order itself would be strengthened. The problem is that the SDGs promote a notion of the "national" rule of law, based on the protection of the state, not the citizenry, and this would presumably legitimize some state actions that run counter to the establishment of a supranational order.

26. Previously, the Millennium Development Goals (MDGs, 2000) focused on the rule of law as an international mechanism ${ }^{44}$ ("International Rule of Law") to prevent war and its social consequences and sought to protect citizens against state (and third party) repression by strengthening human rights, democracy and good governance, relying on the decisions of the International Court of Justice to strengthen peace, security, disarmament, human rights, sustainable development and international law.

27. Without excluding the previous goals or minimizing their risks, the 2015 SDGs, based on the resolutions and decisions of the Security Council and the General Assembly (e.g., A/RES.48 /132; A/RES/49/194; A/RES/50/179; A/RES/51/96; A/RES/52/125; A/RES/53/142; A/RES/55/99; A/ RES/55/221), as well as the reports of the UN Secretary General (e.g., S/2004/616), began to attribute to the rule of law a more "national" connotation ${ }^{45}$, aiming to achieve more just, peaceful and inclusive societies $^{46}$, free from fear and violence, with inclusive access to justice and effective and accountable institutions. To this end -and here lies the crux of the matter- States must strengthen and protect themselves against their forces of disaggregation ${ }^{47}$, through a gradual process of "securitization" of the rule of law and empowerment of their forces of order and security, legitimizing a coercion that can -and tends- to distort and undermine the idea the rule of law. Among these disintegration factors would be, including (according to the policies of some member states), internal and external "confrontations" with the "traditional family", the Christian roots of their societies and national sovereignty.

28. For years, the United Nations (UN) has been promoting the idea that security is a necessary precondition for the development of human rights, sustainable development and the rule of law. Its historical antecedent was the 1993 World Conference on Human Rights, which included security and criminal justice within the scope of the rule of law. This idea was repeatedly reproduced by the General Assembly, reinforced by the "Brahimi Report" of $2000^{48}$ and by the Secretary-General's Report to the Security Council in 2005, when the terms security and development were associated and the notion of "collective security" was exalted ${ }^{49}$. The rule of law assumes the role of social cohesion and peace builder, as guarantor of the effectiveness of law and justice and against misery, fear and human indignity.

29. With the 2005 World Summit, the strengthening of the rule of law became the central and permanent focus of the General Assembly and the Secretary General's reports, which went on to present it as the only reasonable framework for the advancement of security and this, in turn, as the vital precondition for the progress and development of human rights. For this purpose, judicial, police and prison reforms are supported. In turn, with the 2012 High-Level Declaration, the right to development is strongly added and, from then on, the rule of law is definitively enshrined as the basic element of public order and the authority of the State in the struggle against its disintegrating or predatory forces. The strengthening of the national police and judicial and penitentiary institutions is advocated in order to maintain peace and order, an idea that is repeated in the Development Agenda for 2030 Global

${ }^{44}$ L. Zeng, Contemporary International Law and China's Peaceful Development, Springer, Singapore, 2021.

45 T. EsKelinen, "Interpreting the Sustainable Development Goals through the Perspectives of Utopia and Governance", Forum for Development Studies, Vol. 48, nº 2, 2021, pp. 179-197.

46 T. A. Novitz, M. Pieraccini, Legal Perspectives on Sustainability, University of Bristol Press, Bristol, 2020, p. 78.

47 S. LuCarelli, "The EU Migration System and Global Justice: An Introduction", en M. Ceccorulli, E. Fassi, S. LuCAReLLI (coords.), The EU Migration System of Governance, Palgrave Macmillan, Cham, 2021, pp. 1-32.

${ }^{48}$ P. Van Elsuwege, F. Gremmelprez, "Protecting the rule of law in the EU legal order: a constitutional role for the court of justice", European Constitutional Law Review, Vol. 16, n 1, 2020, pp. 8-32.

49 J. MülLER, Reforming the United Nations, Vol. 8, Brill Nijhoff, Leiden, 2021, p. 211. 
Development Agenda ${ }^{50}$, with the notion of well-being ${ }^{51}$. The United Nations Security Council frequently refers to "rule of law vacuum" 52 , "citizen security", "social order" and even "development" to call for the strengthening of state security forces, whose law enforcement can be dysfunctional, illegitimate and unable to control crime, violence and social disorder. It may even distort the very notion of the rule of law.

30. Thus, in practice, the change in the priority focus of the rule of law (from the international focus of the MDGs to the national focus of the SDGs) has not favored European public order, but the international public order of each EU Member State (which must fight against its "disaggregating forces"), which at the very least hinders the process of formation and consolidation of a European and supranational public order.

31. This attitude of exaltation of their own international public order on the part of some of the EU member states had already been observed prior to the assumption of the commitments derived from the SDGs. In fact, only a year before, it has been necessary the reparation of "European values" by the European Court of Human Rights (ECHR) regarding the best interests of the child (Mennesson and Labasse cases, 2014) $)^{53}$, making it prevail over the international public order of the French State in a matter involving the refusal to register the filiation of minors born under a surrogacy contract in favor of the commissioning parents. Subsequent to the ODS, in 2018, the CJEU has done the same-Coman and others case- $-{ }^{54}$ in which it has highlighted the right of free movement of same-sex marriages contracted in the territory of the Union, extending the quality of "spouse" to the same-sex partner of an EU citizen who has married in any of the Member States in accordance with their civil legislation, imposing itself on the international public order of Romania, whose legislation prohibits this type of marriage and denies it any effect that it may generate because it is considered to be contrary to the values and principles of its society ${ }^{55}$.

32. A year earlier, in 2017, the Commission had initiated the above-mentioned art. 7 procedure against Poland and the European Parliament requested the same (approved the proposal with 448 votes in favor and 197 against) in relation to Hungary in 2018, still pending before the Council. The procedures aim to determine the risk of violation of the rule of law, so that, if the Council reaches such a conclusion, no immediate consequences would yet arise for those countries ${ }^{56}$.

33. Moreover, even if the suspension of the voting rights of one of these countries is ultimately successful, the other country could veto the suspension of the first country's voting rights ${ }^{57}$. This further underlines the importance of the above-mentioned action of the European courts ${ }^{58}$, even though the

50 J. Telleria, J. Garcia-Arias, "The fantasmatic narrative of 'sustainable development'. A political analysis of the 2030 Global Development Agenda”, Environment and Planning C: Politics and Space, May 2021, DOI: 23996544211018214.

51 Vid Note 45.

${ }^{52}$ R. Blair, "UN Peacekeeping and the Rule of Law", American Political Science Review, Vol. 115, nº 1, 2021, pp. 51-68.

53 A. Chmielarz-Grochal, "European standards applied by administrative courts in resolving cross-border problems of citizenship and transcription of civil status certificates", Acta Universitatis Lodziensis. Folia Iuridica, Vol. 93, n 1, 2020, 137-154.

${ }^{4}$ D. Kochenov, U. Belavusau, "Same-Sex Spouses: More Free Movement, but What About Marriage? Coman: Case C-673/16, Coman et al. v. Inspectoratul General Pentru Imigrări, Judgement of the Court of Justice (Grand Chamber) of 5 June 2018, EU: C: 2018: 385", Common Market Law Review, 57, n 1, 2020, pp. 227-242.

${ }_{55}$ F. HamiLton, "NH v Lenford: one further step in the continuing evolution of sexual orientation non-discrimination rights before the European Union", GenIUS, 2021, retrieved from http://centaur.reading.ac.uk/97559/1/3\%20March\%20NH\%20Lenford.pdf

56 Vid Note 6.

57 A. Bozóki, D. HegedÜs, "The rise of authoritarianism in the European Union: A hybrid regime in Hungary", en J. MACKERT, H. Wolf, B. S. TuRner (coords.), The Condition of Democracy, Routledge, Abingdon, 2021, pp. 143-165.

${ }^{58}$ Regarding the independence of the judiciary, for example, the Court of Justice in 2018 considered itself competent, even ordering in April 2020, based on the four appeals for failure to comply with the European Commission's judicial reforms (and also on requests promoted by Polish judges themselves and preliminary rulings raised by other national courts) the suspension of the new disciplinary body created by the Polish Law and Justice party -in power since 2010- to investigate and sanction judges not aligned with the country's right-wing nationalist government. With regard to Hungary, the Court of Justice of the 
repeated failures of both countries to comply with the decisions of the CJEU have not led to any accountability demands on either of them.

\section{SDG 16: horizontality and verticality of peace, justice and strong institutions}

34. SDG 16 encompasses three fundamental, integrated and equal areas: peace, justice and strong institutions ("Promote peaceful and inclusive societies for sustainable development, facilitate access to justice for all and build effective, accountable and inclusive institutions at all levels"). Despite the interconnectedness with which they have been conceived, their practical implementation varies from country to country. For example, while Western European countries take into account the "horizontality" of these areas, Eastern European countries consider their "verticality", subordinating peace and justice to the existence of strong institutions.

35. The facts indicate that these two conceptions have a different impact on the rule of law and fundamental rights and freedoms. While horizontality leads to integration, verticality leads to the marginalization and exclusion of certain uncomfortable or undesirable individuals (Muslim immigrants, refugees, the LGBT community, political leftists, etc.). Moreover, it suggests a confrontation between values (European vs. national), types of public order (European vs. international and national) and democracies (liberal vs. illiberal). At stake are the pluralism of society, non-discrimination, tolerance, justice, solidarity and equality between women and men (TEU, Art. 2, second part). Naturally, issues that directly or indirectly relate to the family are affected thereby, because the positions of national authorities may transgress European norms and values.

36. It is worth recalling here that the rule of law is a necessary prerequisite for the protection of both fundamental values and the rights and duties enshrined in international law and in the EU's own treaties (or those of the EU with third countries or groups of countries) and can both promote European public order and the international public order of its member states, depending on the emphasis given to it. As written in the introduction to this research, SDG 16, by emphasizing the national dimension of the rule of law, favors international public order, which is useful for the conservative and extreme rightwing political parties.

37. Conservative parties, across the right-wing political spectrum (and with a special emphasis on the extreme right-wing) often advocate for the defense of what they consider to be "genuinely national values" ${ }^{59}$ The exaltation of international public order as an expression of national sovereignty plays a role of defending the moral, social and legal order of the country, the fundamental and inalienable values and principles of its states, in line with the collective interests and existence of their societies. That is why the Central and Eastern European states argue that both fundamental values and the European public order, still in the process of formation, are factors of disintegration due to "meddling" in their internal affairs. And the traditional Christian family is, for these countries, in the view of the political parties controlling the government, a very relevant issue of a domestic nature ${ }^{60}$.

38. Countries with authoritarian drifts such as Hungary, Poland, the Philippines, Turkey, Russia or China are in an active process of producing binding norms, including constitutional, procedural, penal

European Union has focused on recent legislative reforms limiting the rights of civil society, minorities or the restriction and criminalization of the right to asylum or even the prohibition of activities of the Central European University of Budapest financed by tycoon George Soros (Case C-66/18, judgment of the Court of Justice of October 6, 2020).

${ }^{59}$ A. InOtal, Hungary: “Euroscepticism and Nationalism”, en M. KaEding, J. PollaK, P. SchmidT (coords.), Euroscepticism and the Future of Europe, Palgrave Macmillan, Cham, 2021, pp. 59-64.

${ }^{60}$ D. SziKra, D. Szelewa, "Do Central and Eastern European countries fit the 'Western' picture? The example of family policies in Hungary and Poland”, en C. KLENNER, S. LEIBER (coord.), Welfare states and gender inequality in Central and Eastern Europe. Continuity and post-socialist transformation in the EU Member States, Etui, Brussels, 2010, pp. 81-114. 
and penitentiary reforms that increase the centralization and empowerment of the state, while limiting the basic rights of groups considered undesirable by undermining fundamental and inalienable values of states and the cultural and religious roots of their societies, which includes the family ${ }^{61}$. A few examples will suffice to illustrate this point in relation to Hungary and Poland, two countries that are producing a political, legal and institutional headache in the EU.

39. Concerning Hungary: (1) adopted in December 2020 a reform of its constitution expressly prohibiting adoption by same-sex couples; (2) "hot returns" without examination of possible asylum cases, despite the CJEU decision of December 17, 2020, which has even led to the suspension of the Frontex mission in the country in January 2021. There is an official rejection of Muslim asylum seekers for disrupting the traditional Caucasian-Christian model of their society. Its legislation even provides for the possibility of detention for up to 3 years in detention centers for irregular immigrants, usually Syrians or Iraqis arriving from Serbia, even if they were asylum seekers intending to go to other EU countries (it should be recalled that EU legislation only allow this restriction when it is essential for registration purposes or in case they stay irregularly on European territory and there is a regularly issued expulsion order on the person); (4) the new transparency law (popularly known as "Stop Soros law"), is also symptomatic of this aversion to the potential danger posed by non-Christian migrants and refugees. To reduce their chances of remaining in Hungarian territory, the new law criminalizes assistance to irregular immigrants, even to advise them, guide them or submit their applications asylum application. In these cases, the rule covers both the natural person (imprisonment for up to one year) and non-governmental organizations (obligation to: (a) register with the jurisdictional authorities of the territorial circumscription, (b) declaration of the amount received from the foreigner -EU Member States or third States- when it exceeds 1. 1,400 euros, as well as the name of the donors, and (c) publicity indicating their status as "organization receiving foreign aid" or, if applicable, "organization with foreign capital". In both cases, most of them are financed by George Soros'foundations and operate in the migratory and anti-corruption fields, which has generated a discrimination towards the entities and people they intend to help, such as Transparency International, the Hungarian Union for Civil Liberties or the Helsinki Committee, the only entity that does it for free and that has favorable decisions from the European Court of Human Rights); (4) the attempt to make the Central European University unviable, either by foreign funding (Soros), or by the added obligation for foreign universities or universities with foreign capital operating in the country to have a campus in their country of origin, which does not exist (a law that gives the state greater power of control over universities to combat the ideas of Víktor Orbán's enemy n ${ }^{\circ} 1$, Hungarian-Jewish American tycoon and philanthropist George Soros ${ }^{62}$ on liberal, open and progressive societies -his Open Society Foundations supports educational and civil society strengthening projects developed, among others, by the Central European University of Budapest- interpreted as a plan to undermine European Christian culture through the "flood" of Muslim immigrants) $)^{63}$; (5) the constitutional reform prohibiting the settlement in the country of the foreign population, except those of European origin, under the argument that the ethnic composition of its population cannot be changed by any "external will" (understand, the EU and its migration policy, which establishes the distribution in the form of quotas of asylum seekers among its member states; Hungary, without taking in any refugees, has appealed to the European courts against the quota system agreed by a majority in the EU and against the relocation measures of the 1200 refugees -0 . $02 \%$ of its population- from Greece, Italy and Germany. In addition, he continues to offer strong resistance to EU migration and refugee policy with his leadership of the "Visegrad Group" - or "V4", which also encompasses Slovakia, Poland and the Czech Republic). Indeed, Orbán claims in his speeches that immi-

${ }^{61}$ K. Weyland, "Populism as a Political Strategy: An Approach's Enduring -and Increasing-Advantages", Political Studies, Vol. 69, n 21, 2021, pp. 185-189.

${ }^{62}$ A. LANGER, "The eternal George Soros: The rise of an antisemitic and Islamophobic conspiracy theory", en A. ÖNNERFORS, A. Krouwel (coords.), Europe: Continent of Conspiracies. Conspiracies Theories in and about Europe, Routledge, Abingdon, 2021, pp. 163-184.

${ }^{63}$ C. Lamour, "Orbán Urbi et Orbi: Christianity as a Nodal Point of Radical-right Populism”, Politics and Religion, May 2021, pp. 1-27. 
grants and refugees are a threat to "Christian civilization" ${ }^{64}$. Interestingly, foreigners represent only $1.5 \%$ of the country's population, and almost $70 \%$ of this group are Europeans ${ }^{65}$. In all the above examples, the idea of family is central. Avoid, with international public order and national public order, the idea of full equality between all individuals being tucked away. Some are more equal than others. The basic argument is the imperative need to protect the traditional Christian family from factors that put it at risk. The governmental position of the Hungarian far-right party -Fidesz- is to prevent the "contamination" of that model of family ${ }^{66}$ : traditional and Christian. This includes the rejection of non-Caucasian and especially non-Christian immigrants and refugees, members of the LGBT community and their gay partners, all those who help these groups and, of course, Europe's hated law and order, for meddling in its internal affairs.

40. With regard to Poland: (1) constitutional reform allowing the sanctioning of judges who publicly criticize the erosion of the independence of the Judiciary in relation to the Executive Branch, which already controls the Supreme Court ${ }^{67}$. As far as this investigation is concerned, many of the replaced judges were obstructing government measures related to abortion bans, LGBT restrictions and hindering Muslim refugees' asylum claims ${ }^{68}$; (2) struggle against "European liberalism", which embraces a pluralistic society, which would therefore admit the presence, on equal terms, of non-Caucasian and non-Christian individuals among its people, with their customs that are potentially disaggregated from the traditional family model and their socio-cultural and religious roots ${ }^{69}$; (3) enormous empowerment of the police, subordinated to the Executive Branch, with the purpose of carrying out political and legal measures related to the centralization of power and the preservation of the fundamental values of the state and its Christian roots, including the family as its fundamental nucleus; (4) alarming politicization of the Public Prosecutor's Office (direct control of the Executive Branch) with the same goal ${ }^{70}$; (5) political control of the Constitutional Court by changing its members, in order to unblock laws banning abortion or limiting public space to certain groups considered undesirable and destabilizing for society: LGBT (there are municipalities considered "free of LGBT ideology" since 2020) or immigrants (especially Muslims, blacks, etc.) ${ }^{71}$; (6) control of the civil service of civil servants, local administrations (reduction to two terms of office of mayors to eliminate opposition in wealthy cities such as Krakow, Warsaw or Wroclaw); (7) greater control of public media (press, radio and television), to prevent the dissemination of ideas contrary to the government, including the pluralism of society or the fundamental values of the $\mathrm{EU}^{72}$; (8) reduction of the female role to that of mother ${ }^{73}$ (even with the elimination of the subject of gender equality in textbooks through educational counter-reform); (10) illegalization of abortion by the Constitutional Court in 2020 in cases of fetal malformation (the legal assumptions are rape, incest

${ }^{64}$ A. BozókI, S. Cueva, “Anti-Genderismus in Europa. Xenophobia and Power Politics: The Hungarian Far Right”, Berlín, De Gruyter, 2021, pp. 109-120, retrieved from https://www.degruyter.com/document/doi/10.14361/9783839453155-008/html

${ }_{65}$ A. Biró-NagY, "Orbán's political jackpot: migration and the Hungarian electorate", Journal of Ethnic and Migration Studies, IF 3.116, 2021, pp. 1-20.

66 Vid Note 58.

${ }^{67}$ I. Jelić, D. Kapetanakis, "European Judicial Supervision of the Rule of Law: The Protection of the Independence of National Judges by the CJEU and the ECtHR", Hague Journal on the Rule of Law, Vol. 13, n 1, 2021, pp. 1-33.

68 Vid Note 62.

${ }^{69}$ F. Melito, "Finding the roots of neo-traditionalist populism in Poland: 'Cultural displacement'and European integration”, New Perspectives. Interdisciplinary Journal of Central \& East European Politics and International Relations, Vol. 29, $\mathrm{n}^{\mathrm{o}} 1,2021$, pp. 23-44.

70 A. E. Demczuk, "The Discriminatory Legalism Strategy and Hate Speech Cases in Poland. The Role of the Commissioner for Human Rights in Fighting Discrimination", Annales Universitatis Mariae Curie-Skłodowska, sectio K-Politologia ,Vol. 27, no 2, 2021, pp. 127-148.

71 Vid Note 14.

72 D. Drozdzewski, P. Matusz, "Operationalising memory and identity politics to influence public opinion of refugees: A snapshot from Poland”, Political Geography, Vol. 86, n 6, 2021, ID 102366, retrieved from

https://reader.elsevier.com/reader/sd/pii/S0962629821000263?token=94FE94EE102A5BFE69C4322D136CEAC1045 CE808F7929892104C070583D5A71FE54F0858BAAA5F74719E8191796D2B00\&originRegion=eu-west-1\&originCreation $=20210611210443$

73 Vid Note 19. 
and serious risk to the mother's health) and, logically ${ }^{74},(11)$ an exorbitant fear of refugees (especially Syrians, "because they are carriers of diseases eradicated in Europe") ${ }^{75}$. Above all, Christianity has been used as an essential factor of social cohesion, as a way of repudiating the "foreign and Muslim enemy that invades us and tries to destroy our Caucasian and Christian civilization".

41. What is happening in several countries differs fundamentally from the idea of citizen empowerment previously envisaged in the 2000 Millennium Development Goals (MDGs) and even from the other goals of the current $2015 \mathrm{SDGs}^{76}$. The increased police power derived from the dominance of strong institutions is the corollary of the far-right political discourse in several European countries: the preservation of Christian values and roots, pointed out as fundamental and inalienable of their societies ${ }^{77}$.

42. The horizontality of the three areas included in SDG 16 would allow the State to combat more effectively several of its "internal" disintegrating forces (such as poverty, various injustices and iniquities, violence and widespread criminality, etc.), as well as to reach -although apparently less effectively than with verticality- "foreign" disintegrating forces such as immigration, refugees, international terrorism, cybercrime or organized crime (the latter two because of their international base and/or connections).

43. Under this perspective, while horizontality (peace, justice and strong institutions) would boost social cohesion through the inclusion of all national or foreign individuals (protective public order, such as that of the EU), verticality (peace and justice subordinated to strong institutions) would "do so" through a "process of condensation" in which the public space of certain national and foreign elements considered harmful to society and the state would be reduced ${ }^{78}$. In the first case, the main focus is on the LGBT community, supporters of the progressive political left, Muslim immigrants already in the country and, in the second case, Muslim refugees, blacks, Asians, especially those professing different religions or possessing marriage-related traditions different from the traditional Christian model (as in the case of polygamy among male Muslims, who can marry up to four wives).

44. In this point xenophobic discourses often intermingle with the need to preserve the traditional Christian family model. So, taking up ideas previously expressed at the beginning of this text, international public order and internal public order act together to conjure up the excessively permissive and dangerous European public order. Under this particular view, countries like Hungary and Poland (although this is also observed, with different degrees, in France, Romania, Czech Republic, Italy, Spain) would be doing Europe a favour, fighting like lone knights against the destruction of their cultural and religious roots and culture. Europe should thank them, according to recent pronouncements by political leaders in these countries ${ }^{79}$.

45. When it is inserted into a warmongering political speech that a particular society can only aspire to be more just and prosperous with greater empowerment of public institutions and greater state control over certain potentially harmful and destabilizing groups, it seeks to legitimize the exercise of a police power whose ultimate goal would supposedly be social stability achieved through the preserva-

\footnotetext{
${ }^{74}$ A. GliszczyŃska-Grabias, W. Sadurski, “The Judgment That Wasn't (But Which Nearly Brought Poland to a Standstill): 'Judgment' of the Polish Constitutional Tribunal of 22 October 2020, K1/20", European Constitutional Law Review, Vol. 17, $\mathrm{n}^{\circ} 1,2021,130-153$.

${ }^{75}$ E. M. GoźDZiaK, Human Trafficking as a New (In) Security Threat, Palgrave Macmillan, Cham, 2021, pp. 66-79.

${ }^{76}$ E. De Jong, M. J. ViJge, "From Millennium to Sustainable Development Goals: Evolving discourses and their reflection in policy coherence for development", Earth System Governance, n 7, 2021, pp. 32-45.

${ }_{77}$ N. Morieson, Religion and the Populist Radical Right: Secular Christianism and Populism in Western Europe, Vernon Press, Wilmington, 2021, p. 23.

78 D. ToshKov, E. KortensKa, "Does Immigration undermine public support for integration in the European Union?", Journal of Common Market Studies, Vol. 53, n $\mathrm{n}^{\mathrm{T}}$ 4, 2015, pp. 910-925.

79 I. Yilmaz, N. Morieson, "How Are Religious Emotions Instrumentalized in the Supply of and Demand for Populism?", European Center for Populism Studies, May 2021, retrieved from https://www.populismstudies.org/how-are-religious-emotions-instrumentalized-in-the-supply-of-and-demand-for-populism/
} 
tion and promotion of the "general interest", wielded as a bastion of morality, health, peace and citizen security. The use of military terminology in the discourses leads to the search for public enemies: immigrants, homosexuals, refugees, Muslims, the media (not aligned with the political ideology), "rebel" judges, etc., including all those who help or support them ${ }^{80}$. They are the bad people, the enemies who must be repelled. Naturally, there is a lot of demagogy in the populist narrative.

46. Reinforcing the repressive capacity of the state to maintain the "normalcy of its rule of law" jeopardizes rights and freedoms and can lead to social and, perhaps, ideological control ${ }^{81}$. The risk is high and is already being verified in several parts of the world, as the State has the power and the tools to impose its will. In the name of a fairer and more inclusive society, injustices can be committed, and rights and freedoms can be restricted. In other words, the objective of preserving the traditional and Christian family model leaves a harmful wake for gay couples who wish to adopt a child and constitute a family, single-parent families and, with great impact, families who fail to obtain international protection through the granting of refugee status.

47. The CJEU's condemnation of Hungary in 2017 focused on both violations of the EU Charter of Fundamental Rights (respect for private and family life, freedom of association and protection of personal data) and restrictions on the free movement of capital by the "Stop Soros" transparency law (discrimination of treatment between domestic and cross-border movements without any objective difference). In turn, the December 2020 decision has done so on the basis of the inhumane treatment conferred on asylum seekers ${ }^{82}$ (detained between 2015 and 2018 in the transit/return zones -closed since May 2020- for several weeks or months, often in conditions of isolation and with insufficient and inadequate food, in violation of the assumptions provided by European regulations), the lack of guarantee of effective access to international protection for people who tried to access the country from Serbia and the absence of protection for children and vulnerable people. The fear of macular to the traditional Christian family is leading to the adoption of measures contrary to European public order, European regulations and the fundamental values of the EU.

48. Neither constructive dialogue and political pressure nor the preventive and sanctioning mechanisms provided for in the TEU have so far succeeded in preventing the occurrence of episodes contrary to the common and fundamental values provided for in Article 21 of the $\mathrm{TEU}^{83}$. In fact, with the feeling that the European Council will not succeed in solving the problem, we are seeing the adoption of even more draconian measures towards non-Caucasian and Christian asylum seekers (this is the case in Denmark).

49. Despite the initiative of the European Parliament -with the rejection of Spain (PP), Germany (CDU) and Italy (Forza Italia)-, the opening by the European Commission of proceedings against Hungary (for the serious deterioration of democracy, the rule of law and rights and freedoms) and the activation of Art. 7, first part, TEU by the European Council (a mechanism for monitoring and preserving the rule of law, created in 2014, which is based on the existence of a serious and persistent violation of the common values of the EU and consists of a systemic threat to all its member states), the maximum sanction of withdrawal of voting rights is almost impossible to apply in practice due to the prerequisite

\footnotetext{
${ }^{80}$ E. AytaÇ, Ç. Ali, E. Ezgi, “Partisanship, elite messages, and support for populism in power”, European Political Science Review, Vol. 13, no 1, 2021, pp. 23-39.

81 L. Hamid, J. Wouters, "Rule of law and areas of limited statehood: introduction and perspective", en L. Hamid, J. Wouters (coords.), Rule of Law and Areas of Limited Statehood. Domestic and International Dimensions, Edward Elgar Publishing, Massachusetts, 2021, pp. 2-22.

${ }^{82}$ V. CzInA, "Hungary as a Norm Entrepreneur in Migration Policy", Intersections. East European Journal of Society and Politics, Vol. 7, no 1, 2021, pp. 22-39.

83 S. Progin-Theuerkauf, "Defining the Boundaries of the Future Common European Asylum System with the Help of Hungary?", European Papers-A Journal on Law and Integration, Vol. 6, n 1, 2021, pp. 7-15.
} 
of unanimity ${ }^{84}$. With this legal difficulty and the appeasement policy of the Von der Leyen Commission, there is a risk that authoritarianism will be further consolidated on this side of Europe and, what is worse, it expands along with the populist wave that can be observed in all countries.

50. In the case of Poland, the first country subject to the European mechanism, consultation, evaluation and dialogue with the EU on violations of the rule of law (first phase), recommendations to correct the infringements detected (second phase) and the application of sanctions such as the withdrawal of voting rights (third phase) presents an added difficulty, since it is the EU's sixth largest economy, the main ally in Central and Eastern Europe and the first recipient of European funds.

51. The strengthening of the state, the traditional Christian family and society according to the vision of the Law and Justice party invokes national sovereignty, international and national public order and its peculiar notion of the rule of law. The verticality in the interpretation of SDG 16 suggests that fundamental rights and freedoms can be "flexibilized" by populist governments. Based on their distinction from human rights, which are universal, the rule of law and national and international public order as a sovereign expression of the State can legitimize constitutional and penal reforms that are dangerous to the rights and freedoms of certain communities. Therefore, the horizontality between strong institutions, peace and justice should receive greater attention from all actors (politicians, academics, civil society organizations, etc.), since the prioritization of strong institutions over the other areas of SDG 16 helps far-right populist movements to publicly assign the enemies of the traditional Christian family.

52. In both countries, the main political parties defend the idea that the "traditional Christian family" (consisting of a woman and a man), as the fundamental core of society, is at risk due to its exposure to various factors considered harmful, such as immigration, leftist and LGBT ideologies, Islamism and even the possible existence of a European public order whose values no longer seem to be fully shared, including the idea of social pluralism, non-discrimination, tolerance, justice, solidarity and equality (TEU, art. 2). Furthermore, the EU legal order requires uniformity, legal certainty and cooperation of the Member States.

53. The empowerment of the state and the profuse issuing of mandatory laws by countries with authoritarian drifts (and even "slightly" autocratic), such as Hungary, Poland, the Philippines, Russia, Turkey, Brazil, etc., to achieve "collective and national objectives" tends to deviate from the rule of law. The invocation of arguments such as international public order, sovereignty, intransigence of fundamental values or non-interference in internal affairs is leading them towards the formation and consolidation of police states that seek to legitimize themselves in elections to achieve solid institutions that, in the end, pursue legally and ethically questionable ends ${ }^{85}$.

54. In the case of Western European countries, it is reasonable to expect them to combat their destabilizing forces within the legality and democratic normalcy of a liberal rule of law, with a public policy essentially protective of fundamental rights and freedoms enshrined in the constitution and recognized by international law ${ }^{86}$. However, when, instead of horizontality, a structure marked by verticality is established, that is, peace and justice are subordinated to solid institutions, the rule of law breaks down and public order tends to assume a leading role, valuing more vigorously certain elements or social conducts to the detriment of others, which may even become punishable with the legal reforms carried out in recent years. Broadly speaking, the understanding of SDG 16 is giving rise to a growing dichotomy

\footnotetext{
${ }^{84}$ Vid Note 6.

${ }^{85}$ F. Zoll, L. Wortham, "Weaponizing judicial discipline: Poland”, en R. Devlin, S. Wildeman (coords.), Disciplining Judges. Contemporary Challenges and Controversies, Edward Elgar Publishing, Massachusetts, 2021, pp. 278-307.

${ }^{86}$ A. M. Del VeCCHIO, "Orientamenti e tendenze in tema di soluzione delle controversie internazionali (alla luce dei principi di tutela dei diritti umani fondamentali)", Studi Urbinati, A-Scienze giuridiche, politiche ed economiche, Vol. 53, $\mathrm{n}^{\circ}$ 1, 2021, pp. 39-84.
} 
in Europe. On the Western side, a European public policy protective, aggregating and inclusive, and on the Eastern side, an international public order, directive, disintegrating and excluding in relation to EU values and law, wielded to defend its particular national vision of society: the national vision on the national society, not the EU vision on a supposed European society sharing the same values.

55. The difference in conceptions, interpretations and applications of the rules in these two environments (West and East) finds important political and social reflections, because if in the first case all individuals are considered elements to be protected, regardless of their origin, religion, race, etc., in the second case it can be attempted to reduce -and in fact it is already happening- the protection of certain individuals whose behaviors or beliefs are considered as disintegrating forces of the State: homosexuals, immigrants, refugees, people with different political ideologies, etc.

56. Recent official pronouncements by Jair Bolsonaro (Brazil, independent candidate negotiating to join the Patriot Party for the 2022 elections), Rodrigo Duterte (Philippines, Philippine Democratic Party-People Power), Víktor Orbán (Hungary, Fidesz-Hungarian Civic Union), Marine Le Pen (France, National Alliance), Tomio Okamura (Czech Republic, Freedom and Direct Democracy), Geert Wilders (Netherlands, Party for Freedom), Andrzej Duda and Karoslaw Kaczynski (Poland, Law and Justice), Santiago Abascal (Spain, Vox); Matteo Salvini (Italy, Northern League), Jõrg Meuthen (Germany, Alternative for Germany) or Norbert Hofer (Austria, Freedom Party of Austria) usually identify the forces of disintegration of the state and Christian-rooted society and, of course, of their traditional family model.

57. In states where the most conservative parties have taken over the government, the risk of legitimizing a "witch hunt" against Muslims, homosexuals, the political left, certain journalists and human rights defenders, the poor, immigrants, refugees, etc., is very real. To show how far this has gone, Fidez (the Hungarian far-right party) considers Muslims, who constitute only $0.05 \%$ of its population ${ }^{87}$, as the enemy of true national and Christian values. Moreover, a few months ago, both Hungary and Poland boasted about the approval of budget allocations and the fund for economic recovery (NextGeneratio$\mathrm{nEU}$ program) without the need to make them conditional on respect for the rule of law and European values. In fact, they even openly criticize them while deviating from democracy and violating the human rights and fundamental freedoms of various groups, shielded by the supposed sovereign defense of their values and roots $^{88}$.

58. In addition to international public order, erected as a bulwark for the defense of national sovereignty, domestic public order is also being configured to guide certain behaviors and punish (or punish more severely) others, without preventing administrative discretionality from turning into arbitrariness and even discrimination in the service of certain political ideologies or restricting rights and freedoms now considered contrary to the "collective interests" of their societies. Based on a specific (vertical) perception of SDG 16, the aim is to achieve peace and justice tailored to political objectives -which do not coincide with the universality intended in the conception of the SDGs (not even SDG 16)and an attempt to legitimize a repressive state system that directly affects various groups.

59. The countries that are most favorable to the integration of all individuals and that conceive of the horizontality of peace, justice and strong institutions of SDG 16 are those that tend to invoke equality, social inclusion and citizen empowerment, particularly female empowerment. In contrast, the least favorable countries are those that subordinate peace and justice to strong institutions (verticality), to embrace as a priority -and increasingly selectively- the social inclusion of individuals who share or

87 M. C. BALDINGER, "Neo-feudalism and Neo-traditionalism: The Intersection of Cultural Discourse and Economic Policies in Fidesz's Hungary”, 2021, DI https://dspace.cuni.cz/handle/20.500.11956/12662, retrieved from https://dspace.cuno.cz/ handle/20.500.11956/124662? show=full

${ }^{88}$ M. Blauberger, V. VAn HÜLlen, “Conditionality of EU funds: an instrument to enforce EU fundamental values?”, Journal of European Integration, Vol. 43, $\mathrm{n}^{\circ}$ 1, 2021, pp. 1-16. 
accept their specific vision of society to the detriment of all others, especially non-Caucasians or those who profess non-Christian religions or whose model of marriage or family departs from the traditional types of their societies, even in violation of arts. 8 and 12 of the European Convention on Human Rights, which covers all families ${ }^{89}$.

60. SDG 16 has served as a support for conservative political forces that exalt sovereignty and international public order, while establishing a national public order with an increasingly police-like profile. So far, the institutional mechanisms of the EU have given rather tepid responses to these rightwing populist exaltations, whose common denominator is their exacerbated nationalism.

61. Apart from the constitutionalization of what certain political parties consider to be fundamental and inalienable values of society (achieving with their enshrinement at the constitutional level the necessary congruence with the international order), in Europe the lukewarmness is partly explained by the fact that the influential and conservative European People's Party, which has dominated the EU political scene for two decades, encompassing most of the Christian Democratic parties in the region and from which the last presidents of the European Commission have emerged, is increasingly dependent on the votes of the parties of the Eastern European countries ${ }^{90}$.

62. Even the departure of Fidesz from the European People's Party has not changed the situation, as it has the support of several parties with which it could form a front even further to the right of the political spectrum ${ }^{91}$. However, the main stumbling blocks to the support of the European People's Party (EPP) ${ }^{92}$ have not been the defense of Christian roots and the traditional Christian family model of their societies, but the politicization of the judiciary and the increasing reduction of the separation of the three powers. Although not a priority for political movements in Brussels, the sustained idea of protecting Christian values also faces a serious obstacle related to party positioning in the eyes of their electoral bases. This is a calculation that right-wing parties must make in order to position themselves more to the centre (centre-right) or closer to the extreme right, which is the part of the political spectrum that advocates this idea most vehemently.

63. Thus, with strong institutions, prevailing peace and justice, it is possible to point out the set of proposals (some already realized) of these countries. In the case of Europe, for example, with varying degrees one can find ${ }^{93}: 1$. centralization of power; 2 . defense and exaltation of national symbols; 3 . promotion of Christian values and the roots of society; 4. illegalization of parties and non-governmental organizations because of their ideological profile; 5 . economic protectionism; 6 . adoption of restrictive measures regarding abortion; 7. Skepticism regarding the EU and its values; 8. exaltation of nationalism; 9. defense of sovereignty; 10 . selective expulsion of immigrants; 11 . negative conceptions regarding immigrants and refugees; 12. closing of mosques and adoption of measures to contain Islam; 13. generalized and accentuated lowering of taxes; 14 . adoption of policies contrary to gender equality and the LGTB collective; etc.

${ }^{89}$ M. Mouzourakis, "More laws, less law: The European Union's New Pact on Migration and Asylum and the fragmentation of 'asylum seeker' status", European Law Journal, Vol. 27, n 1, 2021, pp. 1-10.

90 W. Palaver, "Collective Identity and Christianity: Europe between Nationalism and an Open Patriotism", Religions, Vol. $12, \mathrm{n}^{\circ} 5,2021$, pp. 339-384.

${ }^{91}$ M. A. Vachudova, "Populism, Democracy, and Party System Change in Europe", Annual Review of Political Science, $\mathrm{n}^{\mathrm{o}} 24,2021$, pp. 471-498.

92 With the Hungarian far-right Fidesz party leaving the grouping prior to its expulsion (which would be in line with the recent change in the EPP's internal rules), the tension has increased. Political parties with a strong view of nationalism and the more traditional notion of marriage and family (contrary to the broader and more modern vision that is being conferred by current European law) remain strong in the European Parliament. Proof of this is its integration into the Conservatives and Reformists Group in the European Parliament, together with the Polish Law and Justice party, and which could represent an East-West split in the EPP. In fact, the far-right is reorganising itself to compete with this party, through a new grouping made up of these two parties plus the Northern League party of the far-right Matteo Salvini.

${ }^{93}$ C. Joppke, Neoliberal Nationalism: Immigration and the Rise of the Populist Right, Cambridge University Press, Cambridge, 2021, p. 233. 
64. The ideas with the greatest support are the selective expulsion of illegal immigrants, the closing of mosques, measures to contain Islam and skepticism towards the EU and its values. In second place, the generalized and accentuated lowering of taxes and political and legal measures against the LGBT community. Third, anti-gender policies and measures. Fourth, measures limiting abortion. Fifth, the centralization of power (this placement is due to the fact that they are constitutionalist parties, and, in some constitutions, political, administrative and legislative decentralization is enshrined). Sixth, the illegalization of political parties and non-governmental organizations based on their ideology. Seventh, the unwavering defense of national symbols and economic protectionism. Eighth, the promotion of Christian values (although it appears in the background of all of them, it comes last because they are secular states, with secular parties and because their political constitutions provide for freedom of religious belief).

65. Although the idea of social inclusiveness of the SDGs in general encompasses all individuals, types of marriage or family models ${ }^{94}$, the international public order and the national rule of law reinforced and sustained by Goal 16 allows the State to "securitize" itself normatively and institutionally to prioritize and consolidate the chosen model, linked to national values and its historical and cultural roots that may oppose European values.

\section{SDG 16: international public order, nationalist politics and the defense of marriage and the traditional Christian family}

66. SDG 16 (abbreviated to "Peace, Justice and Strong Institutions") 95 has embodied with particular force the current vision of the rule of law according to the UN, so that the state's fight against its "disintegrating forces" is often linked to the invocation of national sovereignty, reforms of the penal and penitentiary systems, the empowerment of the police and the military, and the appointment of judges and/or reforms that undermine the independence of the judiciary. This process of "securitization" of the rule of law distorts it and tends to legitimize coercion and restrictions of freedom that directly affect the new family models ${ }^{96}$.

67. Family law (and any other law connected to it, such as freedom of movement and residence, equal marriage, the best interest of the minor, etc.) comes into play in this dichotomy of European public order vs. international public order of the Member States when the political vision -especially the sectarian one- disregards the common and foundational values of the EU and favors a strictly national perspective under the discourse of preservation of morality, good customs and the basic legal principles and values of the Christian roots of society.

68. Same-sex marriage, for example, is an issue that still divides European public opinion today, with: (1) a favorable majority in the Netherlands (91\%), Sweden (90\%), Denmark (87\%), Spain (84\%), Germany (83\%), Ireland (80\%), Belgium (77\%), Luxembourg (75\%), France (67\%), Finland (66\%), Malta (65\%), Austria (62\%), Portugal (61\%), Czech Republic (57\%), Italy and the UK (56\%); (2) a tie in Greece (50\%) and (3) an unfavourable majority in Estonia and Hungary (39\%), Slovenia (38.3\%), Poland (38\%), Croatia and Cyprus (37\%), Slovakia and Lithuania (24\%), Romania (21\%), Latvia (19\%) and Bulgaria (17\%).

${ }^{94}$ P. Krekó, "Populism in Power: The Tribal Challenge", en J. P. Forgas, W. D. Crano, K. Fiedler (coords.), The Psychology of Populism. The Tribal Challenge to Liberal Democracy, Routledge, Abingdon, 2021, pp. 240-257.

95 "Promote peaceful and inclusive societies for sustainable development, facilitate access to justice for all and build effective, accountable and inclusive institutions at all levels".

96 E. Hualmarson, "Border and Rule: Global Migration, Capitalism, and the Rise of Racist Nationalism", Studies in Social Justice, Vol. 15, n 3, 2021, pp. 543-547. 
69. There is not a complete match between public opinion and legislation among these countries $^{97}$. Prior to the recognition of equal marriage ${ }^{98}$, the national legal system allowed registration as a registered partnership in Austria (2010 and 2019), Belgium (2000 and 2003), Denmark (2012), Finland (2002 and 2017), France (1999 and 2013), Germany (2001 and 2017), Ireland (2015), Luxembourg (2004 and 2015), Malta (2014 and 2017), the Netherlands (1998 and 2001), Scotland (2005 and 2014; Gibraltar, 2014 and 2016; United Kingdom (Scotland, 2005 and 2014; Gibraltar, 2014 and 2016; England and Wales, 2005 and 2014 and Northern Ireland, 2005 and 2020) and Sweden (2009). These countries are the ones that, for the most part, because of their history or international commitments, most commonly invoke the SDGs (and invoked the MDGs) related to equality, social inclusion and women's autonomy and empowerment. The same is true for Spain (2005) and Portugal (2010), which recognize the legal figure of equal marriage, but not domestic partnership as a civil status in a national norm. In the opposite direction, Cyprus (2015), Croatia (2014), Czech Republic (2006), Slovenia (2017), Greece (2015), Hungary (2009 and 2010) and Italy (2016) recognize registration as a de facto union, but not same-sex marriage. In these countries, SDG 16 is interpreted in a way that primarily -and increasingly selectively- encompasses the social inclusion covered by other SDGs. In other words, the inclusion is often that of their own nationals to the detriment of foreigners, especially non-Caucasians, those who profess non-Christian religions or whose marriage or family patterns deviate from the traditional types of their societies. Their conservative political forces exalt sovereignty and international law and order at the same time as they establish an increasingly policed domestic law and order. The situation is the same for countries that do not legally recognize either cohabitation or equal marriage: Bulgaria, Estonia, Latvia, Lithuania, Poland, Romania, Slovakia and Estonia.

70. In relation to these countries, national sovereignty and national and international public order are the basis for the invocation of traditionalism, public morals and Christian-rooted good customs related to marriage and the family. Thus, the national rule of law embodied in SDG 16, by strengthening the state against its "disintegrating forces", would "legitimize" public authorities to take measures to defend the essential Christian-rooted values of their communities against internal and external attacking factors (in the latter case, among others and despite their adherence, certain EU values would be included). SDG 16, by legitimizing the fight against "destructive forces" in society, naturally hampers the consolidation of the still incipient European public order, requiring the intervention of European courts.

71. If one looks at the stance of certain political segments in countries such as Poland, Hungary, Romania and several others, one will see that there are more or less constant attacks (or attempted attacks $)^{99}$ on the rule of law ${ }^{100}$, some of them related to the new family models. The preservation of the traditional apostolic and Roman Catholic family model, associated with the defense of Europe's Christian roots and the sovereignty of EU member states, however, are increasingly coming from those countries which, without European aid, would possibly plummet economically and in the level of welfare of their populations.

72. The exaltation of fundamental national values by some countries, as if they did not correspond -or even compete- with the fundamental values of the EU that they formally share and which they are obliged to respect through their accessions, reveals a political vision of society and the family that is usually categorized as conservative or ultra-conservative. The way of preserving them, based on national sovereignty, public order (with emphasis on international public order) and the national rule of law that SDG 16 upholds, could become a serious obstacle to the consolidation of a supranational set of

${ }^{97}$ L. S. CAhill, "Same-Sex Marriage and Catholicism. Dialogue, Learning, and Change", en J. Patrick Hornbeck, M. A. Norko, A. O’Donnell, J. C. Seitz (coords.), More than a Monologue: Sexual Diversity and the Catholic Church. Voices of Our Times, Fordham University Press, New York, 2014, pp. 141-155.

${ }_{98}$ M. GiERYCZ, European Dispute over the Concept of Man, Springer, Cham, 2021, pp. 79-132.

99 Most of the attacks (or attempted attacks) targeted the independence of the judiciary, the weakening of anti-corruption mechanisms, minority rights, media plurality and freedom, freedom of expression and the situation of migrants and refugees.

100 Vid Note 85. 
values that were already considered, at least formally, to be shared. The same fate could befall European public order, which is seen as a "foreign" body that weakens the national values of those countries that, for this reason, seek to avoid it.

73. For the time being, the institutional mechanisms (tainted by the lack of political initiative on the part of the member states, especially in certain political sectors) have led to lukewarm responses to these nationalist exaltations against the new models of marriage and the family. As mentioned above, part of the blame lies with the European People's Party and its dependence on the votes of right-wing parties in Eastern Europe.

74. Both the issue of marriage and, more broadly, that of the family, would be under the gaze of conservative nationalist (or even far-right) parties in countries with a Christian majority (Poland with $90.46 \%$, although declining since the peak of $97.20 \%$ in $1990^{101}$; Hungary, with $67.36 \%$, in free fall from $89.84 \%$ in $1945^{102}$, and Italy, with $79.39 \%$, in continuous decline from $98.18 \%$ in 1945 , except for small upturns in 2000 and 2005 , with $85.44 \%$ and $85.90 \%$, respectively ${ }^{103}$ ).

75. This means that the traditional Christian nuclear family ${ }^{104}$ is and will be extolled by rightwing nationalist parties which, based on the defense of a strong sovereignty, international public order and a national rule of law (SDG 16), will continue to exalt Christian roots and virtues and restrict rights and new marriage and family models, considered "attacking and disintegrating" their national values. They would even look for scapegoats: immigrants, refugees, Muslims and even Europeanist values.

76. Indeed, it is quite symptomatic that the head of Poland's nationalist government, Mateusz Morawiecki, in July 2020, after the summit that approved the new EU budget and the coronavirus pandemic recovery fund, boasted of achieving different allocations (reconstruction fund and credits, agricultural subsidies and cohesion funds) without making it conditional on respect for the rule of law and European values. The same goes for Hungary, whose Prime Minister Viktor Orbán openly criticizes European values, also deviating from democracy and violating human rights.

77. This being the case, in the event of a real East-West split in the EPP, which the party itself has been avoiding for several years, the EU could be dichotomized in terms of public order, with the European in the West and the international in the East, with marriage, the family, family rights and other related issues being discussed, among others.

78. Chancellor Angela Merkel's Germany has not escaped criticism as its domestic and international detractors hold her government partly responsible for the gradual deterioration of the rule of law in neighbouring countries, and thus for the growing prominence of the international law and order of these countries and the weakening of the yet to be forged European law and order by prioritizing her country's commercial interests and the integrity of the single market in its relations with Poland and Hungary, to the detriment of the defence of the EU's common values ${ }^{105}$.

79. This growing process of securitization of the rule of law and consolidation of the international public order of member countries, supported by SDG 16, may be a potential danger to freedoms by

\footnotetext{
${ }_{101}$ Datosmacro, Poland, religion (2010 data): https://datosmacro.expansion.com/demografia/religiones/polonia

102 Datosmacro, Hungary, religion (2010 data): https://datosmacro.expansion.com/demografia/religiones/hungria\#: :tex$\mathrm{t}=\mathrm{Seg} \% \mathrm{C} 3 \% \mathrm{BAn} \% 201 \mathrm{las} \% 20 \% \mathrm{C} 3 \%$ BAltimas\%20encuestas\%2C\%20un,\%25\%20al\%2072\%2C84\%25

${ }_{103}$ Datosmacro, Italy, religion (2010 data): https://datosmacro.expansion.com/demografia/religiones/italia

${ }^{104}$ In the case of Poland, for example, a country with deep-rooted Christianity, social rejection of egalitarian marriages or new family forms is still high (around 38\%). In the case of Hungary, its $27.16 \%$ of non-believers or its tiny $0.05 \%$ of Muslims are considered by the Fidesz party as "enemies" of the genuine national and Christian values it seeks to protect.

${ }^{105}$ M. Henke, R. MAHER, "The populist challenge to European defense", Journal of European Public Policy, Vol. 28, nº 3, 2021, pp. 389-406.
} 
restricting rights enshrined by the EU for individuals and family groups (marriage, movement, establishment/residence), in their most up-to-date models according to EU law and jurisprudence ${ }^{106}$.

80. What can be perceived is that the lack of political consensus on the definition of "family" between countries ends up, in practice, "legitimizing" the vision of a specific society (or the vision given by the dominant political parties at a specific historical moment) on this issue. In order to defend it, the traditional family is continually associated with national values with Christian roots. Although the idea of social inclusivity of the SDGs in general encompasses any and all types of marriage and family, the international public order and especially the national rule of law upheld by SDG 16 allows the state to "securitize" itself normatively and institutionally in order to prioritize and consolidate the chosen model, coupled with national values that may even oppose European values that are no longer shared.

81. This is the case of Poland's President Andrzej Duda, linked to the nationalist-conservative force Law and Justice, which defends the value of the traditional family. So does Hungary, whose Viktor Orbán's government recently approved a constitutional reform that prevents adoption by homosexual couples (with the alleged purpose of protecting children and defending Christian culture). In fact, the text states that children must have a father and a mother, and that only registered married couples may adopt.

\section{Conclusions}

82. International public policy may embody national values that do not coincide with fundamental European values. While formally these values are common and shared, some EU member states seem to be moving further and further away from them in practice. Parties further to the right of the political spectrum, especially in Central and Eastern Europe, are securitizing the state against the "disintegrating forces" of their Christian-rooted societies: migrants, refugees, Islamism, the political left, and so on. SDG 16 legitimizes this protection of the state by giving greater weight to the national rule of law. In this context, European public order, which is still in the making, loses its place as it becomes an "external factor" that weakens national values. As long as it continues along this path, the rule of law will not be respected.

${ }^{106}$ Not far behind are families formed from transgender people (or even their marriage). 